\title{
DESKRIPSI INTIMACY, PASSION, DAN COMMITMENT PASANGAN SUAMI ISTRI YANG MENIKAH SECARA KATOLIK
}

\author{
Octavia Putri $^{1}$, Clara R. P. Ajisuksmo \\ ${ }^{1}$ Jurusan Psikologi, Universitas Tarumanagara, Jakarta \\ Email: octaviaputritjajadi@hotmail.com \\ ${ }^{2}$ Fakultas Psikologi UNIKA Atma Jaya \\ Email: clara.as@atmajaya.ac.id
}

\begin{abstract}
ABSTRAK
Pernikahan merupakan perjanjian antara pria dan wanita untuk membentuk keluarga bersama. Selain menikah secara agama, pasangan suami istri diwajibkan untuk mengurus dokumen di catatan sipil, sehingga pasangan suami istri ini dinyatakan sah dalam pernikahan. Hubungan pernikahan pun tidak lepas dari cinta. Menurut Sternberg, cinta terdiri dari tiga komponen, yakni intimacy, passion, dan commitment. Setiap komponen memiliki elemen tersendiri, yaitu intimacy terdiri dari sepuluh elemen, passion terdiri dari lima elemen, dan commitment terdiri dari tujuh elemen. Penelitian ini bertujuan untuk melihat gambaran intimacy, passion, dan commitment pada pasangan yang menikah secara Katolik, dengan mengunakan skala cinta Sternberg. Penelitian ini mengunakan metode kualitatif dengan pengumpulan data melalui wawancara. Subjek dalam penelitian ini adalah tiga pasang suami istri (6 orang) yang menikah secara Katolik dan memiliki anak. Peneliti menggunakan metode analisis Fenomenologi. Kredibilitas penelitian dilihat dari hasil jawaban setiap subjek, kemudian dianalisis secara mendalam. Hasil penelitian dari keenam subjek hampir berbeda pada setiap komponen. Intimacy ditunjukkan dengan keingian meningkatkan kesejahteraan pasangan, di mana ketiga suami melakukan peran dalam bertanggungjawab untuk mencari nafkah bagi keluarga; pemahaman satu sama lain; dan menjalin komunikasi terbuka. Sementara dari ketiga istri intimacy terbentuk karena istri sebagai partner dalam menjaga hubungan pernikahan, yakni dengan memberikan perhatian kepada suami, mencoba saling mengenal, dan memberikan dukungan untuk suami terutama ketika sakit. Selanjutnya dari passion, hanya satu subjek yang menyebutkan bahwa ia tertarik pada pasangan secara fisik dan kelima subjek menyebutkan bukan faktor fisik melainkan kecocokan kepribadian.Commitment terlihat dari pengorbanan yang berupa tindakan dan keyakinan hubungan dapat terus berlanjut. Hasil penemuan teori segitiga Sternberg memiliki tiga komponen, tetapi yang paling utama dipenelitian ini adalah komitmen sebagai komponen utama.
\end{abstract}

Kata kunci: intimacy, passion, commitment, Sternberg's Love scale, pernikahan

\section{PENDAHULUAN}

\section{Latar Belakang}

Pernikahan adalah janji antara laki-laki dan perempuan yang sah secara Negara, sehingga diijinkan untuk kesatuan biologis dan memiliki peran masing-masing. Menurut Olson dan DeFrain (2002), pernikahan adalah sekumpulan emosi dan komitmen yang sah antara dua orang untuk berbagi perasaan, kedekatan secara fisik, memiliki pembagian tugas masing-masing, serta sebagai sumber penghasilan. Sementara menurut Girgis, George, dan Anderson (2012), pernikahan adalah kesatuan antara laki-laki dan perempuan dengan membuat janji permanent dan adanya komitment dikedua pihak yang secara natural diisi dengan tindakan yang berkiatan dengan perilaku proses reproduksi, sehingga melahirkan anak untuk melanjutkan keturunan. Bisa disimpulkan bahwa pernikahan adalah janji dengan komitment antara laki-laki dan perempuan yang sah, sehingga bisa menghasilkan keturunan.

Bagi pasangan katolik, pernikahan termasuk dalam Sakramen. Untuk melangsungkan pernikahan (dalam Penjelasan Sakramen, t.th), calon pasangan suami istri wajib mendaftarkan diri minimal lima bulan di gereja paroki, kemudian bertemu dengan pastor paroki serta menyerahkan formulir minimal empat bulan sebelum tanggal pernikahan. Calon pasangan suami-istri melengkapi dokumen-dokumen yang dibutuhkan gereja, seperti: surat baptis terbaru, fotokopi sertifikat 
kursus perkawinan, mengisi formulir yang ditanda tangani ketua lingkungan, fotokopi Kartu Tanda Penduduk (KTP), dan surat keterangan (jika calon mempelai berasal dari luar paroki atau berasal dari TNI/POLRI) (Penjelasan Sakramen, t.th)

Dokumen di catatan sipil pun wajib untuk diperhatikan. Menurut Amirsyah (2013), beberapa dokumen yang perlu dipersiapkan, yaitu: fotokopi surat baptis terbaru dan surat nikah gereja; fotokopi akte kelahiran, fotokopi KTP, fotokopi Kartu Keluarga (KK) yang dilegalisir kelurahan; formulir surat keterangan menikah dari kelurahan; dan fotokopi KTP saksi perkawinan.

Persiapan khusus pernikahan untuk calon pengantin selambat-lambatnya dilakukan dalam kurun waktu dua bulan. Persiapan khusus pernikahan dilakukan calon pasangan suami-istri untuk mempelajari peran, ritus, dan simbolisme liturgi pernikahan; calon suami istri juga harus mempersiapkan buku teks liturgi pernikahan; calon suami istri menghafalkan teks-teks penting terutama janji pernikahan; calon suami-istri mengaku dosa sebelum liturgi pernikahan untuk mempersiapkan batin; dan mempelai latihan upacara pernikahan (Suryanugraha, 2013).

Selain persiapan dari sisi calon suami istri, pastoral juga mengambil peran penting dalam kesiapan pernikahan yaitu penyelidikan Kanonik. Penyelidikan Kanonik ini berupa pertanyaan, misalnya: makna kesetiaan seumur hidup, makna monogami dan tak terceraikan, pendidikan anak, serta bagaimana merencanakan keluarga yang bahagia dan sejahtera, dan berkualitas dalam iman. Penyelidikan Kanonik ini sangat menekankan pada komitmen. Pengertian dalam penyelidikan Kanonik, pernikahan adalah sebuah pilihan yang didasarkan pada komitmen pribadi yang mengandung tanggung jawab seumur hidup (Kriswantara, 2013).

Dalam pernikahan, pasangan suami istri membutuhkan cinta yang membuat pasangan suami-istri dapat bertahan dalam menghadapi masalah-masalah di dalam pernikahan. Cinta adalah kumpulan emosi yang dirasakan oleh dua orang karena saling tertarik satu sama lain. Sternberg (dalam Wirawan, 1999), menyimpulkan bahwa ketika orang merasakan cinta, ia akan mengalami sekumpulan perasaan, hasrat, dan pikiran yang menjadi satu. Lebih lanjut, menurut Sternberg (1998), cinta merupakan sebuah kisah yang merefleksikan kepribadian, minat, dan perasaan orang terhadap suatu hubungan.

Pernikahan adalah proses dari mencintai karena ada keterikatan yang terjalin di dalam sebuah hubungan. Di Indonesia pernikahan yang sah, tercantum pada Undang-Undang Republik Indonesia nomor 1 tahun 1974 tentang Perkawinan, pada Bab 1 Pasal 2 ayat 1, berbunyi: "Perkawinan adalah sah apabila dilakukan menurut hukum masing-masing agama dan kepercayaannya itu." (dalam UUD, 1974)

Berdasarkan data yang diberikan pengadilan tinggi agama DKI Jakarta tentang jumlah pernikahan pada tahun 2009 banyaknya pernikahan 10.988, sedangkan angka perceraian sebanyak 820, yakni sebanyak 7,46\%. Pada tahun 2010, jumlah pernikahan sebanyak 5.606, sedangkan angka perceraian sebanyak 342, yakni sebanyak 6,1\% (Jakarta dalam angka, 2014). Bisa dilihat bahwa jumlah angka perceraian menurun di kedua tahun ini.

Di sisi lain perceraian, ada pernikahan yang dapat bertahan. Survei yang dilakukan oleh AARP pada tahun 2004 (dalam Santrock, 2011), 3 dari 4 orang yang bercerai mengatakan bahwa bercerai adalah pilihan yang tepat. Enam puluh enam persen perceraian karena gugatan dari pihak istri. Sementara, 1.148 dengan subjek berusia 40-79 tahun, menyatakan bahwa mereka tetap menikah karena anak. Data di Keuskupan Agung Jakarta (KAJ), pada tahun 2012 pasangan 
yang menikah secara Katolik serta memiliki pasangan yang beragama Katolik berjumlah 2.874, sedangkan pada tahun 2013 berjumlah 2.584 (Prasojo, 2014).

Ketika laki-laki dan perempuan dipersatukan di dalam pernikahan, bisa dikatakan bahwa salah satu dasarnya adalah cinta (Skolnick, 1983; Kameyer, 1987). Menurut Sternberg (1998), teori segitiga cinta melibatkan kombinasi antara keintiman (intimacy), gairah (passion), dan komitmen (commitment). Lebih lanjut Sternberg mengatakan bahwa kombinasi cinta ini bersifat dinamis, sedangkan dalam pernikahan Katolik yang memiliki sifat tak terceraikan secara tidak langsung memaksa pasangan suami istri ini untuk bertahan dalam pernikahan. Sehingga membutuhkan penelitian lebih lanjut mengenai gambaran cinta Sternberg dan pasangan yang menikah secara Katolik.

Lemiuex dan Hale (2002) melakukan penelitian lanjutan terkait ketiga komponen cinta Sternberg pada orang yang berpacaran, bertunangan, dan menikah. Subjek yang digunakan sebanyak 446 orang dan mengunakan satu arah analisis varian. Hasil yang ditemukan bahwa intimacy dan relationship memiliki korelasi sedang negatif sama seperti passion dan relationship. Commitment dan relationship memiliki korelasi sedang positif. Kemudian, subjek yang berpacaran mendapatkan skor rendah pada intimacy dan passion. Subjek yang bertunangan mendapatkan skor tinggi pada intimacy dan passion. Subjek yang menikah mendapatkan skor rendah. Lalu, komponen commitment meningkat dari subjek yang berpacaran ke subjek yang menikah.

Sebelumnya, Lemiuex dan Hale (2000) melakukan penelitian tentang intimacy, passion, dan commitment pada individu yang menikah. Mereka melibatkan 213 subjek yang sudah menikah. Ketiga komponen ternyata memberikan pengaruh pada hubungan untuk saling berkorban. Tetapi, skor pria lebih tinggi dari pada skor wanita dalam komponen intimacy.

\section{Rumusan Masalah}

Pernikahan Katolik memiliki kekhasan yakni tidak dapat diceraikan dalam keadaan apapun, sehingga menuntut suami dan istri untuk terus bersama, pada kenyataannya cinta menurut teori segitiga Sternberg (1998) dalam pernikahan memiliki tiga komponen yang bersifat dinamis. Makna pernikahan suami dan istri yang berbeda dapat mempengaruhi cinta itu sendiri. Dari penjabaran di atas, peneliti ingin melihat bagaimana gambaran intimacy, passion, dan commitment dalam pernikahan Katolik.

\section{METODE PENELITIAN}

\section{Desain Penelitian}

Menurut Creswell (2003), pendekatan kualitatif memiliki prosedur yang lengkap terutama karena konteks yang spesifik. Dalam penelitian ini konteks spesifik yang dimaksud adalah pasangan yang menikah secara Katolik. Penelitian ini mengunakan wawancara tidak struktur dan peneliti harus membangun raport pada responden penelitian. Subjek hanya menjawab pertanyaan yang diberikan oleh peneliti. Sementara, Tracy (2013) mengatakan bahwa konteks dalam penelitian kualitatif peneliti harus mengenali topik penelitian, permasalahan, proses penelitian yang sistematik dan menginterpretasi data yang diperoleh. Pada penelitian ini, pendekatan yang dipilih adalah pendekatan kualitatif karena peneliti ingin melihat makna intimacy, passion, dan commitment dalam pernikahan Katolik. 


\section{Partisipan Penelitian}

Partisipan dalam penelitian ini adalah tiga pasang suami-istri (enam orang), yang memiliki karakteristik berikut: (a) pasangan suami istri. Pasangan suami istri ini telah mengikat janji dan berada di dalam sebuah hubungan pernikahan, sehingga mereka memiliki makna pernikahan masing-masing, (b) menikah secara Katolik, dan (c) memiliki anak. Kriteria pasangan memiliki anak ini dikarenakan faktor anak dalam pernikahan memiliki dua sisi, bahwa anak bisa menjadi pengikat komitmen penikahan atau bahkan bisa membuat ketegangan dalam pernikahan, sehingga faktor anak menjadi karakteristik penting.

Tabel 1. Gambaran Partisipan

\begin{tabular}{|c|c|c|c|c|c|c|}
\hline \multirow[t]{2}{*}{ Keterangan } & \multicolumn{2}{|c|}{ Pasangan 1} & \multicolumn{2}{|c|}{ Pasangan 2} & \multicolumn{2}{|c|}{ Pasangan 3} \\
\hline & $\begin{array}{c}\text { Arka } \\
\text { (suami) }\end{array}$ & $\begin{array}{l}\text { Amira } \\
\text { (istri) }\end{array}$ & $\begin{array}{l}\text { Baim } \\
\text { (suami) }\end{array}$ & $\begin{array}{l}\text { Bella } \\
\text { (istri) }\end{array}$ & $\begin{array}{l}\text { Cakra } \\
\text { (suami) }\end{array}$ & Chia (istri) \\
\hline Usia & 39 tahun & 40 tahun & 49 tahun & 46 tahun & 61 tahun & 60 tahun \\
\hline Agama & Katolik & Katolik & Katolik & Katolik & Katolik & Katolik \\
\hline Pekerjaan & $\begin{array}{c}\text { Karyawan } \\
\text { (Kepala } \\
\text { Bidang } \\
\text { Lapangan) }\end{array}$ & $\begin{array}{c}\text { Ibu rumah } \\
\text { tangga }\end{array}$ & $\begin{array}{c}\text { Karyawan } \\
\text { (General } \\
\text { Manager) }\end{array}$ & $\begin{array}{c}\text { Ibu rumah } \\
\text { tangga }\end{array}$ & $\begin{array}{c}\text { Pensiun } \\
\text { karyawan } \\
\text { Bank }\end{array}$ & $\begin{array}{c}\text { Ibu rumah } \\
\text { tangga }\end{array}$ \\
\hline $\begin{array}{l}\text { Pendidikan } \\
\text { terakhir }\end{array}$ & SMA & D3 & S1 & $\mathrm{S} 1$ & SMP & SMP \\
\hline $\begin{array}{l}\text { Lama } \\
\text { menikah }\end{array}$ & 16 & & 20 & hun & 35 & hun \\
\hline $\begin{array}{l}\text { Jumlah } \\
\text { anak }\end{array}$ & 2 putra $(1$ & $\begin{array}{l}\text { tahun dan } \\
\text { un) }\end{array}$ & $\begin{array}{r}1 \text { putra }(2 \\
\text { putri }(16 \text { tah } \\
7 \text { ta }\end{array}$ & $\begin{array}{l}\text { ahun) \& } 3 \\
\text { n, 11tahun, } \\
\text { un) }\end{array}$ & 2 putra $(34$ & $\begin{array}{l}\text { ahun dan } 32 \\
\text { an) }\end{array}$ \\
\hline
\end{tabular}

\section{Teknik Sampling}

Metode pengambilan partisipan dalam penelitian ini adalah purposive sampling karena peneliti memilih subjek tertentu yang dianggap dapat memberikan infomasi yang sesuai dengan tujuan penelitian ini. Sebelum menentukan subjek, maka peneliti bertanya kepada ketua lingkungan dan melakukan observasi pada partisipan, apakah partisipan memiliki karakteristik yang dibutuhkan peneliti. Selanjutnya, bertanya pada subjek apakah mereka menikah secara Katolik. Selanjutnya, peneliti mengunakan panduan wawancara yang setiap item pertanyaan berdasarkan alat ukur cinta dari Sternberg.

\section{Metode Analisis Data}

Peneliti menggunakan metode analisis data fenomenologi. Yin (2011) menjelaskan, fenomenologi berfokus pada pengalaman hidup individu. Peneliti fenomenologi tertarik pada sifat atau makna dari pertanyaan penelitian, sehingga membahas pengalaman tersebut. Reid, Flowers, dan Larkin 
(2005), selama proses analisis, peneliti merefleksikan prasangkanya tentang data yang didapat. Transkrip dikodekan dengan rinci dan dilihat dari sudut pandang peneliti.

\section{Kredibilitas dan Dependabilitas Penelitian}

Hasil jawaban dari setiap subjek dianalisis secara mendalam dan dilihat secara berpasangan dari masing-masing pasangan suami istri. Apakah data yang diterima sama atau malah justru berbeda, jika hasil yang didapat berbeda, maka peneliti akan menghubungi subjek lagi untuk mengkonfirmasi kebenaran. Jika hasil yang diterima sama, maka peneliti akan langsung menganalisis setiap jawaban subjek sehingga mendapatkan gambaran intimacy, passion, dan commitment. Bentuk analisis akan menjawab permasalahan penelitian ini.

\section{HASIL DAN PEMBAHASAN}

\section{Intimacy}

Dimensi pertama dari komponen intimacy adalah keinginan meningkatkan kesejahteraan pasangan pertama, terlihat intimacy yang ditampilkan berupa perilaku pembagian peran. Arka bertanggungjawab pada bagian finansial terutama untuk menyekolahan anak dan mencukupi kebutuhan keluarga, sedangkan Amira menjaga anak-anak yang berperan sebagai ibu rumah tangga. Pada pasangan kedua, Baim dan Bella terlihat intimacy yang ditampilkan berupa sikap. Baim merasa harus bekerja sebaik-baiknya dan semaksimal mungkin, sementara Bella harus bersikap dengan mengerti pasangan dan menjaga rasa saling percaya satu sama lain. Pada pasangan ketiga, Cakra dan Chia memperlihatkan intimacy untuk meningkatkan kesejahteraan pasangan yang melibatkan faktor finansial. Dengan adanya pekerjaan, Cakra merasa dapat meningkatkan kesejahteraan pasangan. Sementara Chia membantu pasangan mencari uang dengan berjualan.

Komponen intimacy, dimensi kedua terkait mengalami bahagia. Arka dan Amira merasa bahagia saat kelahiran anak pertama. Selain itu, menurut Arka, ia merasa percaya, jika mereka bisa menjalankan pembagian peran masing-masing dan Amira percaya, jika mereka bisa menyelesaikan permasalahan yang dihadapi bersama-sama. Pada pasangan kedua, Baim dan Bella merasa keluarga adalah sumber kebahagiaan. Baim merasa bahagia, jika bisa pergi bersama dengan kelaurga dan pasangan. Baim juga merasa sangat percaya pada pasangan bahwa mereka dapat menghadapi permasalahan bersama. Sementara, Bella merasa bahagia, ketika melahirkan anak. Bella sangat percaya pada Baim karena Bella merasa Bella bukan tipe pencemburu. Pada pasangan ketiga, Cakra dan Chia. Cakra dan Chia merasa bahagia jika dapat pergi keluar negeri bersama. Cakra sangat percaya pada pasangan di setiap saat. Chia percaya pada pasangan karena Cakra merupakan orang yang jujur dan sayang pada istri serta keluarga.

Dimensi ketiga dari komponen intimacy adalah menghormati dan menghargai pasangan. Arka merasa bentuk penghormatan pada pasangan berupa perilaku saling menjaga dan menyayangi satu sama lain. Arka merasa bentuk menghargai berupa perilaku dengan cara memberikan kejutan untuk pasangan. Sementara, Amira menghormati pasangan dengan memberikan serta menuruti masukan dari pasangan. Amira merasa bentuk menghargai berupa perilaku saling mengingatkan satu sama lain. Pada Baim merasa menghormati pasangan dengan memberikan apresiasi pada pasangan. Bella merasa menghormati pasangan dengan melayani pasangan terkait hal rumah tangga, tak lupa Bella pun berdoa dan menyiapkan keperluan pasangan. Pada pasangan ketiga, Cakra menghormati pasangan dengan cara menjaga pasangan dan cara 
menghargai dengan menuruti pasangan, sehingga terhindar dari perdebatan. Chia menghormati pasangan dengan cara melayani urusan rumah tangga, seperti memasak.

Dimensi keempat dari komponen intimacy adalah dapat diandalkan saat dibutuhkan oleh pasangan. Arka merasa diandalakan saat ia melakukan pekerjaan laki-laki, seperti menganti gas kompor dan menganti galon air. Amira merasa diandalkan menjalankan peran sebagai ibu rumah tangga, seperti memasak. Baim dan Cakra merasa diandalkan saat mencari nafkah untuk pasangan dan anak-anak. Bella merasa diandalkan saat pasangan sakit dan diperlukan untuk mengantar ke dokter. Chia merasa diandalkan saat pasangan meminta untuk mengelolah keuangan keluarga.

Komponen intimacy pada dimensi kelima adalah saling memahami satu sama lain. Arka merasa dengan saling percaya dan menjalani peran masing-masing, maka ia dan pasangan dapat memahami satu sama lain. Sama seperti Amira yang berpikir bahwa dengan mengurus anak bersama dan mengerti sifat satu sama lain, maka mereka dapat saling memahami. Menurut Baim, di dalam pernikahan harus ada kerjasama, saling komunikasi, dan saling terbuka agar dapat memahmi satu sama lain. Menurut Bella, saling memahami satu sama lain terjalin karena adanya keterbukaan satu sama lain dan harus tahu batasan diri. Pada pasangan ketiga, Cakra dan Chia. Cakra berpikir bahwa memahami pasangan dapat dilihat dari tingkah laku pasangan. Chia berpikir dengan saling terbuka satu sama lain terutama dengan berbincang-bincang, jadi dapat lebih memahami pasangan.

Membagi benda dan diri agar intimacy terbentuk adalah dimensi keenam. Menurut keenam subjek mereka berbagi barang hanya sebatas keperluan rumah tangga. Arka dan pasangan berbagi barang bersama hanya sebatas barang rumah tangga, seperti gelas dan sikat gigi. Arka dan Amira juga harus meminta ijin terlebih dahulu pada pasangan sebelum mengunakan barang bersama. Amira juga seperti Arka yang merasa berbagi barang sebatas keperluan rumah tangga, seperti televisi dan handphone. Menurut Baim, berbagi benda yang dipakai bersama hanya sendok, piring, dan sisir. Cakra berbagi barang seperti handuk, sikat gigi, dan sabun. Menurut Cakra dengan berbagi barang maka merasa menyatu dengan pasangan dan mengurangi pemborosan. Hal ini disetujui oleh Chia yang merasa dengan adanya berbagi barang bersama, maka mereka seperti menyatu. Pada subjek Bella ada barang yang dipakai bersama dengan keluarga yaitu kaos kembar.

Dimensi ketujuh dari intimacy adalah menerima dukungan emosional dari pasangan. Arka mendapatkan dukungan emosional dengan menjalin komunikasi dan merasa diperhatikan. Amira merasa mendapatkan dukungan dari pasangan, ketika diberikan masukan saran. Baim dan Cakra merasa menerima dukungan karena diberi semangat oleh pasangan, tapi Baim merasa pasangan juga menghiburnya, sementara Cakra merasa pasangan memberikan perhatian. Selanjutnya, Bella merasa mendapatkan dukungan emosional karena pasangan tidak menuntut apa-apa. Chia merasa menerima dukungan emosional, ketika diberi perhatian saat sakit.

Dimensi kedelapan dari intimacy adalah memberikan dukungan emosional pada pasangan. Arka memberikan perhatian pada pasangan dengan bentuk perilaku, seperti mencium pasangan sebelum berangkat ke kantor. Amira memberikan semangat dan perhatian pada pasangan. Pada pasangan kedua, Baim dan Bella. Baim mencoba memahami apa yang dirasakan oleh pasangan. Bella merasa dibutuhkan bantuannya saat pasangan sakit. Pada pasangan ketiga, Cakra dan Chia. Cakra memberikan dukungan emosional dengan cara mau memberikan waktu untuk berdiskusi 
bersama dalam menyelesaikan masalah. Chia memberikan dukungan emosional dengan melayani pasangan terutama terkait urusan rumah tangga, seperti memasak.

Komunikasi merupakan elemen dari intimacy kesembilan. Arka merasa komunikasi dapat dilakukan melalui telepon atau cerita setelah aktifitas sepulang dari kantor. Amira pun juga menyetujui bahwa ia dan pasangan, setiap malam bercerita tentang kejadian hari itu. Pasangang kedua, Baim, Bella, Cakra, dan Chia merasa harus saling terbuka satu sama lain, sehingga dapat menyelesaikan permasalahan bersama. Ketika Baim bercerita tentang permasalahan, biasanya pasagan memberikan saran dan menanyakan hal lebih detail terkait permasalahan. Sementara, Bella merasa mereka dengan mudah dapat berbincang-bincang saat menonton televisi atau saat makan bersama. Dengan Cakra melakukan komunikasi terbuka, maka ia akan bisa memperhatikan tingkah laku pasangannya, sedangkan Chia merasa dengan komunikasi terbuka, ia dan pasangan merasa tidak perlu ada yang disembunyikan.

Elemen kesepuluh dari intimacy adalah merasa membutuhkan kehadiran pasangan. Arka membutuhkan pasangan untuk menjalankan peran di dalam rumah tangga. Amira membutuhkan kehadiran pasangan disaat sakit. Menurut pasangan pertama dengan saling intropeksi diri dapat mengurangi permasalahan. Baim merasa membutuhkan pasangan ditengah kesulitan, sedangkan Bella membutuhkan pasangan disaat sendiri karena merasa sepi ketika tidak ada pasangan. Pada pasangan ketiga, Cakra dan Chia merasa saling membutuhkan di saat sakit, mereka merasa bahwa pasangan menunjukkan perhatian lebih di saat sakit. Ketika bertengkar, Cakralah yang memulai percakapan terlebih dahulu karena merasa sudah berkomit untuk tetap menikah sekali seumur hidup dan akan mempertahankan pernikahan hingga maut memisahkan.

\section{Passion}

Komponen segitiga cinta Sternberg berikutnya adalah passion. Pada elemen pertama passion adalah adanya ketertarikan fisik. Dari kelima subjek hanya satu orang yang menyatakan bahwa iya tertarik pada pasangan karena kecantikannya. Kelima subjek menyatakan bahwa mereka tertarik pada pasangan karena kepribadiannya. Arka dan Amira merasa setelah memiliki anak, kontak fisik jarang dilakukan paling hanya sekedar mencium pasangan saat ingin pergi ke kantor. Baim melakukan kontak fisik dengan pasangan yaitu dengan berpegangan tangan tapi terkadang malu melakukannya. Bella mencium pasangan saat pasangan ingin berangkat dan pulang dari kantor. Cakra dan Chia lebih sering melakukan kontak fisik, seperti berciuman.

Elemen kedua dari passion adalah merasakan hasrat yang besar saat harga diri meningkat. Arka merasa bahwa pernikahannya baik akrena telah mendapatkan istri dan anak yang baik. Selain itu, Arka diperbolehkan untuk bergaul dengan orang lain serta mendapatkan kesempatan untuk beradaptasi sendiri dengan lingkungan. Amira merasa bahwa pernikahan bertujuan untuk saling melengkapi satu sama lain dan pasangan membantu Amira untuk beradaptasi dengan lingkungan. Baim merasa harga dirinya meningkat, ketika pasangan membiarkan Baim menjalankan perannya, seperti menjadi kepala keluarga dan melibatkan dalam pengambilan keputusan. Baim merasa dibantu pasangan untuk beradaptasi dengan lingkungan, berbeda dengan Bella yang merasa tidak dibantu sama sekali. Bella merasa pernikahannya bahagia karena adanya berkat Tuhan dan harga dirinya meningkat saat pasangan membanggakan dirinya di depan orang lain. Selanjutnya, Cakra dan Chia merasa pernikahan harus menyatukan visi dan misi agar dapat lebih memahami satu sama lain. Cakra merasa diperhatikan pasangan dari cara berpakaian dan ia berterima kasih dengan cara menunjukkan kemesraan berdua dihadapan umum. Chia merasa harga diri meningkat, ketika dibanggakan oleh pasangan dan Chia merasa dibantu untuk beradaptasi dengan lingkungan oleh pasnagan. 
Elemen passion ketiga, yakni kebutuhan untuk beraffiliasi. Arka merasa senang ketika dapat menjalankan peran masing-masing dalam pengurusan rumah tangga, sedangkan Amira merasa bahwa saling memberi masukan dan memberikan apa yang pasangan inginkan merupakan sebuah bentuk affiliasi. Pada pasangan kedua, Baim dan Bella, keduanya merasa membutuhkan satu sama lain. Baim merasa membutukan bantuan dalam hal memberikan saran dan untuk mengingatkan, sedangkan Bella merasa membutuhkan pasangan untuk mengurus hal finansial dan Bella merasa senang karena pasangan tidak menuntut apa pun dari dirinya. Pada pasangan ketiga, Cakra dan Chia membutuhkan pasangan di saat sakit dan mereka memiliki harapan yang sama terhadap pernikahan mereka yaitu tetap hidup bersama hingga akhir hayat.

Elemen keempat dari passion adalah mendominasi pikiran dan perilaku pasangan. Arka merasa penting untuk mencari nafkah bagi keluarga dan sangat membutuhkan pasangan untuk memikirkan nasib anak-anaknya. Amira merasa ketika tidak ada pasangan, ia takut merasa kesepian dan memikirkan masa depan anak-anaknya. Pada pasangan kedua, Baim dan Bella sama-sama langsung mengkomunikasikan hal yang menganggu pikiran mereka. Pada pasangan ketiga, Cakra dan Chia keduanya menunjukkan perilaku afeksi. Cakra merasa dibahagiakan ketika pasangan memberikan perhatian, sedangkan Chia merasa dibahagiakan ketika pasangan tidak membantah dan berperilaku romantis, seperti mencium pipi kiri-kanan.

Elemen kelima dari passion adalah pemenuhan kebutuhan seksual. Keenam subjek merasa harus saling memenuhi kebutuhan seksual pasangannya dan harus mengkomunikasikan kebutuhan seksualnya. Arka memikirkan pasangan karena masih belum dapat memenuhi harapan pasangannya untuk membeli rumah. Amira memikirkan pasangannya saat melihat film romantis. Baim merasa diperhatikan pasangan dan menurutnya jika tidak ada pasangan, maka ia akan kesulitan dalam berbagai hal. Bella merasa berjodoh dengan pasangan dan tidak berani memikirkan jika tidak ada pasangan disampingnya. Cakra mmeikirkan pasangan dan merasa senang masih bisa bersama. Menurut Cakra, biasanya pasangan tidak menolak untuk melakukan hubungan seksual. Chia pernah terbayang hidup tanpa pasangan dan terbayang pasangan saat pasangan berperilaku mesra.

\section{Commitment}

Komponen berikutnya dari teori segitiga cinta Sternberg adalah commitment. Elemen pertama dalam komponen commitment, yaitu keputusan untuk menjalin hubungan. Pasangan pertama, setelah berkenalan dan tertarik dengan kepribadian pasangan, mereka memutuskan untuk menikah. Arka merasa keputusan terpenting yang diambil adalah saat pasangan harus meninggalkan pekerjaan dan fokus untuk mendidik anak-anak. Amira merasa keputusan terpenting untuk menikah dan harus tetap setia dalam suka dan duka. Pasangan kedua, setelah satu tahun berkenalan dan berpikir bahwa hubungan ini harus lanjut ke jenjang pernikahan, maka mereka memutuskan untuk menikah. Baim merasa keputusan penting yang diambil adalah saat ia dan pasangan harus membeli rumah karena dengan membeli rumah, maka pengeluran lain harus lebih diirit. Bella merasa kepurusan penting yang diambil adalah saat pindah rumah ke Jawa Timur dan sekarang harus kembali ke Jakarta karena tuntutan pekerjaan pasangan. Pasangan ketiga, Cakra dan Chia merasa setelah bertemu dan akrab, mereka memutuskan untuk menikah. Cakra berpikir bahwa pengalamannya dalam pernikahan yang memilki banyak lika-liku itu menuntut Cakra untuk belajar mengenal pasangan. Cakra juga merasa bahwa keputusan untuk menikah merupakan keputusan penting dan tepat. Sejalan dengan pemikiran Cakra, Chia merasa bahwa dalam pernikahan memiliki banyak pengalaman karena mereka menikah dari nol. 
Menurut Chia, keputusan terpenting dalam hidup mereka adalah ketika pasangan pensiun dan ingin membuka usaha sendiri.

Keputusan untuk mempertahankan pasangan adalah elemen kedua. Ketika mereka sudah memutuskan untuk menikah, mempertahankan pernikahan merupakan hal tersulit. Arka dan Amira setuju bahwa mereka mempertahankan pernikahan dan mau memperbaiki hubungan karena anak. Baim merasa bahwa waktulah yang membuat ia ingin terus mempertahankan pernikahan, sementara Bella, Cakra, dan Chia merasa bahwa komitmen serta janji pernikahanlah yang membuat mereka ingin tetap setia dalam untung-malang, sehat-sakit, dan suka-duka.

Elemen ketiga dari commitment adalah pengorbanan. Pengorbanan yang dilakukan oleh keenam subjek berupa tindakan. Arka merasa berkorban untuk pasangan, ketika Arka lebih memilih membawa makanan dari rumah agar dapat menabung untuk membeli pasangan suatu barang yang diinginkan. Amira, Bella, dan Chia merasa berkorban, saat harus melepaskan pekerjaan demi anak-anak. Baim merasa mengorbankan waktu istirahatnya, ketika pasangan meminta tolong untuk menjaga anak-anak. Cakra merasa berkorban saat membantu pasangan.

Adanya harapan dan keyakinan tentang hubungan berlanjut merupakan elemen keempat dari komponen commitment. Keenam subjek merasa bahwa pernikahan merupakan sebuah perjanjian dan jani tersebut harus ditepati, sehingga keenam subjek merasa harus mempertahanakn pernikahan mereka hingga maut memisahkan.

Selanjutnya, elemen kelima, yakni memiliki rencana jangka panjang. Arka dan Bella menginginkan rumah idaman dan lebih memikirkan anak-anak, terutama dengan memberikan kebahagaian bagi keluarganya. Amira dan Baim lebih memikirkan anak-anaknya. Cakra dan Chia memiliki rencana untuk menghabiskan sisa hidup bersama dengan cara saling mengasihi satu sama lain, saling pengertian, dan saling mengalah.

Untuk merealisasikan tujuan hingga tercapai, pada elemen keenam, keenam subjek memiliki sikap tersendiri. Arka dan Baim mencari nafkah lebih giat dan mencari peluang yang lebih baik lagi, yang berbeda adalah Arka harus dapat membahagiakan keluarganya dan Baim harus bisa menjadi teman hidup bagi pasangannya. Amira dan Bella lebih fokus menjaga anak-anak, yang membuat perilaku mereka berbeda adalah Amira merasa harus lebih menahan diri dan Bella merasa harus lebih memahami pasangannya. Cakra memiliki prinsip yaitu apa yang dipersatukan Tuhan tidak boleh diceraikan manusia dan jangan saling menyakiti, sementara Chia berharap keluarganya hidup dalam damai dan tidak meributkan ha-hal kecil.

Elemen ketujuh dari commitment adalah merencanakan hidup bersama. Arka merasa memegang komitment dengan cara saling mengalah agar dapat mempertahankan pernikahan. Amira merasa harus saling mengalah dan saling mengerti satu sama lain. Baim merasa, jika lebih banyak melakukan hal-hal bersama dengan pasangan serta mencoba saling memberi satu sama lain, mungkin pernikahan dapat bertahan dengan lama. Bella merasa dengan saling memahami satu sama lain, saling mengalah, dan terbuka, maka pernikahan dapat bertahan lama. Cakra dan Chia merasa harus saling mengerti dan saling mengalah. Bisa dilihat bahwa keenam subjek merasa untuk hidup bersama, saling mengalah sangatlah dibutuhkan.

Makna pernikahan Katolik pun dijadikan pegangan oleh setiap subjek. Arka merasa menikah sekali seumur hidup hingga maut memisahkan dan tidak berpaling ke lain hati. Amira merasa pernikahan yang menjanjikan untuk hidup semati dalam suka dan duka, serta berada di bawah 
perlindungan Bunda Maria dan Yesus. Baim menyatakan bahwa pernikahan sekali seumur hidup dan jika menghadapi masalah harus diselesaikan tanpa memikirkan jalan untuk berpisah. Bella memaknai pernikahan sebagai perjanjian sakral untuk menikah sekali seumur hidup dengan satu orang. Cakra merasa pernikahan Katolik meruapakan tindakan yang tidak boleh memikirkan diri sendiri karena harus menikah hingga akhir hayat. Chia merasa pernikahan merupakan kesetiaan satu sama lain hingga maut memisahkan.

Pernikahan Katolik berbeda dengan pernikahan agama lain. Hal ini juga disampaikan oleh keenam subjek. Arka merasa bahwa pada agama Katolik, pernikahan dilakukan sekali seumur hidup, sedangkan agama lain mungkin diperbolehkan memiliki banyak pasangan. Amira menanggap bahwa pernikahan Katolik didasari oleh Tuhan Yesus sebagai bukti memegang teguh janji setia hingga mati, sedangkan agama lain boleh kawin cerai. Bella merasa bahwa agama Katolik tidak boleh bercerai, tetapi agama lain bisa bercerai jika memiliki alasan tertentu. Cakra menganggap pernikahan Katolik dilakukan sekali seumur hidup, tidak boleh bercerai, dan tidak boleh memiliki pasangan lain, sedangkan agama lain bisa bercerai dan memiliki banyak pasangan. Chia menganggap pernikahan Katolik tidak boleh bercerai dan hanya setia pada satu orang.

Terkait makna cinta itu sendiri. Menurut Arka, cinta adalah kasih sayang diantara dua orang (pria dan wanita) untuk memenuhi kebutuhan orang yang disayangi, sedangkan menurut Amira, cinta itu untuk mendapatkan dan memberikan perhatian pada orang yang khusus. Cinta menurut Baim adalah perilaku dan harus dilakukan bukan hanya sekedar dibicarakan, sementara cinta menurut Bella merupakan komitmen karena sudah mengambil keputusan untuk bersama. Menurut Cakra, cinta itu ketertarikan seseorang yang berbeda jenis untuk saling mendapatkan dan untuk saling menjaga keutuhannya, sedangkan menurut Chia, cinta itu saling mengasihi satu sama lain, tidak boleh menyombongkan diri atau tinggi hati, dan harus murah hati.

\section{KESIMPULAN DAN SARAN}

\section{Kesimpulan}

Berdasarkan hasil analisis, maka kesimpulan yang diperoleh dari ketiga pasangan adalah:

Perilaku intimacy dari ketiga suami ditunjukkan melalui peran tanggungjawab sebagai pencari nafkah bagi keluarga; pemahaman satu sama lain; dan menjalin komunikasi terbuka. Sementara dari ketiga istri intimacy terbentuk karena istri sebagai partner dalam menjaga hubungan pernikahan, yakni dengan memberikan perhatian kepada suami, mencoba saling mengenal, dan memberikan dukungan untuk suami terutama ketika sakit. Selain itu, pasangan dibutuhkan karena adanya kesepakatan menjalankan peran serta menjadi mitra dalam membantu satu sama lain. Ada penemuan lain terkait salah satu indikator intimacy, yaitu komunikasi. Komunikasi bukan hanya menjadi faktor kecil, melainkan faktor penting di dalam pernikahan. Komunikasi bukan hanya mempengaruhi intimacy, tetapi passion dan commitment pun membutuhkan komunikasi.

Pada passion, hasil yang ditemukan hanya satu subjek yang menyebutkan bahwa responden tertarik pada pasangan secara fisik dan kelima subjek menyebutkan bukan faktor fisik melainkan kecocokan kepribadian untuk saling melengkapi satu sama lain. Selanjutnya, terkait pemenuhan kebutuhan seksual, ketiga pasangan suami istri sama-sama berusaha memenuhi kebutuhan seksual pasangannya dengan cara mengkomunikasikannya. 
Commitment dapat dilihat dari keputusan untuk menikah dengan tujuan membangun keluarga, sehingga mau berkorban satu sama lain. Dalam menghadapi permasalahan rumah tangga, keenam subjek menyatakan bahwa mereka perjanjian pernikahanlah yang membuat mereka mempertahakan pernikahan. Untuk membentuk komitmen, pada awalnya dibutuhkan saling mengenal satu sama lain, sehingga keenam subjek yakin melangkah ke jenjang pernikahan. Komitmenlah yang mempengaruhi pernikahan Katolik, jadi subjek akan melakukan segala cara mempertahankan pernikahan tersebut, sehingga pemaknaan aturan di dalam agama Katolik lebih berperan untuk menjaga komitmen. Komitmen yang mejadi unsur utama diantara kedua komponen lain, membuat definisi cinta Sternberg tetaplah sama karena unsur teori cinta Sternberg adalah adanya ketiga komponen tersebut, sehingga dapat dinyatakan sebagai cinta sejati.

Pernikahan Katolik yang dipahami semua pasangan suami istri adalah harus tetap setia dan sehidup semati, serta tidak mencari jalan pintas untuk berpisah. Keenam subjek merasa harus bisa mempertahankan pernikahan hingga maut memisahkan mereka dengan cara saling memahami satu sama lain. Ketiga pasangan suami istri menghayati janji pernikahan mereka, yaitu tetap setia dalam untung dan malang, sakit dan sehat, suka dan duka.

Teori Segitiga cinta Sternberg yang menyatakan bahwa ketiga komponen bergerak secara dinamis, menjadikan intimacy, passion, dan commitment tetap ada di dalam pernikahan, tetapi tergantung dari makna pernikahan itu sendiri, sehingga ketiga komponen akan bergerak dibatas rendah dan tinggi.

\section{Saran}

Saran metodologis yang dapat diberikan dalam penelitian ini akan lebih baik, jika melakukan triangulasi dengan pihak-pihak yang berkaitan, seperti orangtua pasangan suami istri dan orang terdekat pasangan. Triangulasi berguna untuk mencocokan kembali hasil jawaban subjek apakah jawaban subjek sesuai kenyataan atau tidak. Sementara saran praktis dapat menjadi acuan untuk konselor pernikahan terutama yang bekerja di KAJ, penyelidik kanonik, pastur/romo, bagian kursus perkawinan, komisi keluarga Katolik, dan pasangan Katolik yang akan menikah. Konselor, bagian kursus perkawinan, dan penyidik kanonik dapat menceritakan bahwa di dalam pernikahan Katolik yang monogami dan tak terceraikan pun juga menuntut pasangan untuk saling menghargai satu sama lain, saling memahami, dan saling mencintai (yang terbagi dari intimacy, passion, serta commitment). Untuk komisi keluarga Katolik, penelitian ini dapat digunakan sebagai acuan pembuatan modul seminar. Selanjutnya, untuk pasangan yang akan menikah secara Katolik diharuskan memiliki tujuan pernikahan sendiri dan menghayati janji pernikahan, yang akan menjadi pegangan dalam menghadapi permasalah pernikahan. Pasangan suami istri yang Katolik pun harus tetap setia pada janji pernikahannya yaitu tetap bersama hingga maut memisahkan serta tetap setia dalam untung dan malang, sakit dan sehat, suka dan duka. Hal ini sesuai seperti yang dikatakan Nobert, bahwa cinta kasih suami istri merupakan penyerahan pribadi secara total dan mengingat keperluan anak, dari hakekatnya menuntut sifat tak terceraikan.

\section{Diskusi}

Hasil penemuan dalam penelitian ini adalah teori segitiga Sternberg yang memiliki tiga komponen tidak dapat dipisahkan satu sama lain karena saling berkaitan. Seperti yang dijabarkan pada bagian kesimpulan, komitmenlah yang mempengaruhi pernikahan Katolik, sehingga mereka akan melakukan segala cara untuk mempertahankan pernikahan tersebut. Pemaknaan aturan di dalam agama Katolik untuk menikah sehidup semati lebih berperan untuk menjaga komitmen. Bisa dikatakan bahwa komitmen yang menjadi dasar pernikahan Katolik, sedangkan 
intimacy dan passion merupakan komponen penunjang. Peneliti setuju bahwa teori segitiga cinta Sternberg yang terbagi menjadi intimacy, passion, dan commitment, ketiganya saling melengkapi satu sama lain. Selain itu, penelitian yang dilakukan oleh Herawati dan Syifa a (2008) tentang hubungan antara religiusitas dengan komitmen pernikahan pada pasangan suami istri. Penelitian ini membahas religiusitas dari sisi agama Islam bahwa semakin tinggi tingkat religiusitas maka, semakin tinggi komitmen pernikahan pada pasangan suami istri. Sementara, hasil penemuan lain adalah pada agama Katolik pun komitmen dianggap penting.

Makna monogami, tak terceraikan, dan adanya kesetiaan seumur hidup pada pernikahan Katolik membuat kelima subjek tertarik untuk mempelajari agama Katolik. Pasangan yang awalnya bukan menganut agama Katolik dan ingin menikah secara Katolik diwajibkan untuk mengikuti Katesisasi dan Sakramen Baptis terlebih dahulu, baru setelahnya mengikuti kesiapan pernikahan. Selanjutnya, sakramen pernikahan hanya melekat saat awal mereka menikah, sedangkan persiapan pernikahan terutama dalam penyidikan kanonik yang membahas aturan pernikahan agama Katolik sangatlah melekat pada pasangan Katolik.

Peran gender di dalam pernikahan juga memberikan pengaruh pada pembagian tugas. Tugas suami lebih ke arah mencari nafkah dan membantu mengasuh anak, sedangkan tugas istri lebih menjaga anak-anak dan menjadi ibu rumah tangga. Salah satu tugas istri yang penting adalah mengatur keuangan. Hal ini sesuai dengan ungkapan Olson dan DeFrain (2002), bahwa di dalam pernikahan memiliki pembagian tugas masing-masing. Selanjutnya, Ampa (2011) juga menyatakan bahwa suami yang mencari nafkah zaman sekarang mulai membantu istri dalam pengasuhan anak. Penemuan lain dalam penelitian ini adalah anak di dalam keluarga bukan hanya sebagai faktor komitmen, melainkan sebagai faktor penentu kebahagiaan pasangan suami istri.

Berikutnya, dalam elemen intimacy, pasangan suami istri merasa memiliki kedekatan serta keterikatan satu sama lain. Suami dan istri memiliki keterikatan emosional tersendiri, sehingga mereka saling melengkapi satu sama lain. Hal ini sesuai dengan pernyataan Papalia dan Olds (dalam Papalia, Olds, \& Feldman, 2009), menyebutkan bahwa keintiman melibatkan perasaan saling memiliki antara pasangan untuk membangun hubungan yang kuat, stabil, dekat dan penuh kasih sayang.

Ada penemuan lain terkait salah satu indikator intimacy, yaitu komunikasi. Komunikasi bukan hanya menjadi faktor kecil, melainkan faktor penting di dalam pernikahan. Komunikasi bukan hanya mempengaruhi intimacy, tetapi passion dan commitment pun membutuhkan komunikasi. Hal ini didukung oleh Holley, Haase, dan Levenson (2013), yang melakukan penelitian longitudinal tentang tipe komunikasi pada 127 pasangan suami istri. Ketika pasangan suami istri berdiskusi satu sama lain untuk membahas sebuah permasalahan dari permasalah rumah tangga hingga permasalahan keuangan. Holley, Haase, dan Levenson (2013) mendapatkan hasil tipe demand-withdraw artinya ketika ada satu pihak yang memaksakan kehendak, maka pihak lain cenderung akan mundur dari pembahasan.

\section{Ucapan terima kasih}

Peneliti mengucapkan terima kasih kepada Universitas Katolik Atma Jaya, Jakarta dan Keuskupan Agung Jakarta (KAJ) karena sudah memperbolehkan bekerjasama saat pengambilan data. 


\section{REFERENSI}

Amirsyah. (2013September 2). Pernikahan mudah dan murah di KUA atau kantor catatan sipil. Kompasiana. Diakses dari http://sosbud.kompasiana.com/2013/09/02/pernikahan-mudahdan-murah-di-kuakantor-catatan-sipil-585907.html

Ampa, A. T. (2011). Budaya masyarakat dan impilakasinya terhadap keterlibatan suami dalam kegiatan rumah tangga. Egalita Jurnal Kesetaraan dan Keadilan Gender,4(2), 103-113.

Creswell, J. W. (2003). Research design: Qualitative, Quantitavie, and mixed methods approaches (Ed. 2). California, CA: SAGE Publication.

Girgis, S., George, R., \& Anderson, R. T. (2012). What is marriage?. Harvard Journal of Law and Public Policy, 34(1), 245-287.. retrieved from https://ssrn.com/abstract=1722155

Herawati, P. R. P., \& Syifa ${ }^{\mathrm{ee}}$, R. (2008). Hubungan antara religiusitas dengan komitmen perkawinan pada pasangan suami istri. Diakses pada 26 September 2014, dari http://psychology.uii.ac.id/images/stories/jadwal_kuliah/naskah-publikasi-04320127.pdf

Holley, S. R., Haase, C. M., \& Levenson, R. W. (2013). Age-related changes in demandwithdraw communication behaviors. Journal Marriage Family. 75(4): 822-836.

Badan Pusat Statistik Provinsi DKI. (2014). Jakarta dalam angka 2014.Jakarta: (penerbit)

Kammeyer, C. W. (1987). Marriage and family: A foundation for personal decisions. Massachusetts: Allyn \& Bacon.

Kriswantara, G. (2013). Penyelidikan kanonik: Pastoral persiapan perkawinan secara saksama. Yogyakarta: Kanisius.

Lemieux, R. \& Hale, J. L. (2000). Intimacy, passion, and commitment among married individuals: Futher testing of triangular theory of love. Psychological Reports, Vol. 87, hal. 941-948.

Lemieux, R. \& Hale, J.L (2002). Cross-sectional analysis of intimacy, passion, and commitment: Testing the assumptions of the triangular theory of love. Psychological Reports90, 10091014) Vol. 90, hal. 1009-1014.

Oslon, D. H., \& DeFrain, J. (2002). Marriage and families: Intimacy, diversity, and strengths. (4th ed). New York, NY: McGraw-Hill Companies.

Papalia, Olds, \& Feldman.(2009). Human Development. (11th Ed). Boston, MA: McGraw-Hill Companies.

Prasojo, A. (2014).. Data perkawinan Kkatolik Kkeuskupan Aagung Jjakarta :Komunikasi pribadi. Jakarta: Keuskupan Agung Jakarta.

Penjelasan sakramen-sakramen gereja Katolik. (t. th). Jakarta: Keuskupan Agung Jakarta. Diakses dari http://www.kaj.or.id/dokumen/sakramen-sakramen/penjelasan

Poerwandari, E.K. (2007). Pendekatan kualitatif untuk penelitian perilaku manusia. Jakarta : LPSP3 Universitas Indonesia.

Reid, K., Flowers, P. \& Larkin, M. (2005) Exploring lived experience: An introduction to Interpretative Phenomenological Analysis. The Psychologist, 18(1), 20-23.

Santrock, J. W. (2011). Life-span development. New York: McGraw-Hill.

Skolnick, A. S. (1983). The intimate environment: Exploring marriage and the family. (3rd ed). Toronto: Little, Brown.

Sternberg, R. (1998). Love is a story: A new theory of relationships. New York: Oxford University Press, Inc.

Sterneberg, R. J. \& Barnes, M. (1988). The psychology of love. Haven \& London: Yale University Press.

Tracy, S. J. (2013). Qualitative research methods: Collecting evidence, crafting analysis, communicating impact. West Sussex: Wiley-Blackwell. 
Undang-Undang Republik Indonesia Nomor 1 Tahun 1974 tentang Perkawinan. (2 Januari 1974). Lembaran Negara Republik Indonesia Tahun 1974. Jakarta. Diakses pada 18 Juni 2014, dari http://luk.staff.ugm.ac.id/atur/UU1-1974Perkawinan.pdf

Wirawan, S. (1999). Tipe cinta orang dewasa muda dilihat dari attachment style yang dimiliki (skripsi tidak diterbitkan). Universitas Atma Jaya, Jakarta, Indonesia.

Yin, R. K. (2011). Qualitative research from start to finish. New York, NY: The Guilford Press. 